\section{DETERMINATION OF DEFLECTION BASIN USING PAVEMENT MODELLING COMPUTER PROGRAMS AND FINITE ELEMENT METHOD}

Sri Atmaja P. Rosyidia, Asmah Hamimb, Aizat Mohd Taibb*, Nor Azliana Akmal Jamaludinc, Zubair Ahmed Memond, Nur Izzi Md. Yusoffb, Mohd Rosli Hainine

aDept. of Civil Engineering, Universitas Muhammadiyah Yogyakarta, Yogyakarta, Indonesia

bDept. of Civil Engineering, Universiti Kebangsaan Malaysia, Selangor, Malaysia

cDept. of Computer Science, Universiti Pertahanan Nasional Malaysia, Kuala Lumpur, Malaysia

dDept. of Engineering Management, Prince Sultan University, Saudi Arabia

eDept. of Civil Engineering, College of Engineering, Universiti Malaysia Pahang, Pahang, Malaysia
Article history

Received

4 November 2019

Received in revised form

12 April 2020

Accepted

2 May 2020

Published online

22 June 2020

*Corresponding author amohdtaib@ukm.edu.my

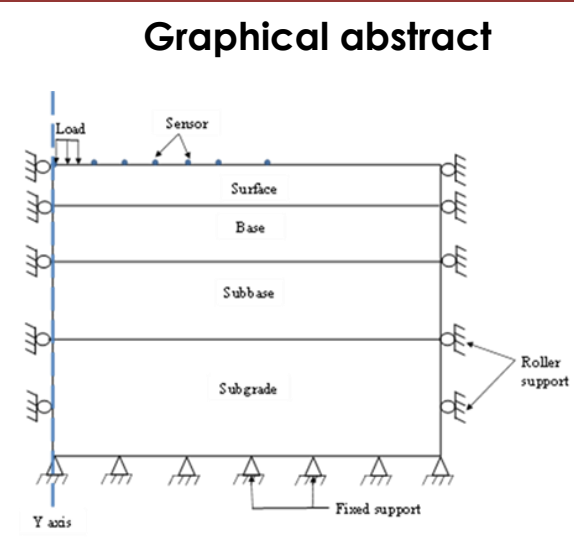

\begin{abstract}
Several methods can be used to model pavement structures, namely multilayered elastic theory (MET), finite element method (FEM), or finite difference method (FDM). In this study, three computer programs, KENLAYER and EVERSTRESS 5.0 which are based on MET, and ANSYS, representing the FEM, are used in Falling Weight Deflectometer (FWD) test on a pavement structure to determine deflection basin. The deflection basin was developed by using the results of vertical deflection from each sensor of an FWD test. In this study, a pavement structure was modelled for three locations of FWD tests, namely $\mathrm{CH} 200, \mathrm{CH} 1450$, and $\mathrm{CH} 2300$. Based on the comparative study, all computer programs show good potential in determining deflection basin, with small percentage of Root Mean Square Error (RMSE) of between $1.00 \%$ to $4.31 \%$ for all models developed by the computer programs and field measurement. In order to obtain a higher accuracy of the FEM, the models considered the dynamic loading, increasing size of model geometry, as well as the reduction of the mesh element sizes. Moreover, changing from static to dynamic loading led to the reduction of percentage in RMSE for CH 200 from $2.41 \%$ to $0.94 \%$. Decreasing size of closer elements of loading region also results in lower percentages of RMSE, calculated at $4.21 \%$ to $3.63 \%$ and $1.20 \%$ to $1.18 \%$ for $\mathrm{CH} 1450$ and $\mathrm{CH} 2300$, respectively. FEM, therefore, is found to be the best method for determining deflection basin of FWD in comparison to other MET computer programs.
\end{abstract}

Keywords: Finite element method, KENLAYER, EVERSTRESS 5.0, falling weight deflectometer, flexible pavement

\begin{abstract}
Abstrak
Beberapa kaedah boleh digunakan untuk model struktur perkerasan, iaitu teori elastik berlapis pelbagai (MET), kaedah unsur terhingga (FEM), atau kaedah perbezaan terhingga (FDM). Dalam kajian ini, tiga program komputer, KENLAYER
\end{abstract}


dan EVERSTRESS 5.0 yang berasaskan MET, dan ANSYS, yang mewakili FEM, digunakan untuk memodelkan ujian Deflectometer Berat (FWD) pada struktur perkerasan dalam menentukan lembangan pesongan. Lembapan pesongan telah dibangunkan dengan menggunakan hasil pesongan menegak dari setiap sensor ujian FWD. Dalam kajian ini, satu struktur turapan dimodelkan untuk tiga lokasi ujian FWD iaitu $\mathrm{CH} 200, \mathrm{CH} 1450$ dan $\mathrm{CH}$ 2300. Berdasarkan kajian komparatif, semua program komputer menunjukkan potensi yang baik dalam menentukan lembangan pesongan, dengan peratusan kecil Root Mean Square Error (RMSE) antara $1.00 \%$ hingga $4.31 \%$ untuk semua model yang dibangunkan oleh program komputer dan ukuran lapangan. Untuk mendapatkan ketepatan yang lebih tinggi dari FEM, model-model tersebut mengambil kira beban dinamik, peningkatan saiz model geometri, serta pengurangan saiz elemen mesh. Lebihlebih lagi, perubahan dari statik ke beban dinamik menyebabkan pengurangan peratusan dalam RMSE bagi CH 200 dari $2.41 \%$ kepada $0.94 \%$. Mengurangkan saiz elemen berhampiran bagi rantau pemuatan juga menghasilkan peratusan RMSE yang lebih rendah, dikira pada $4.21 \%$ kepada $3.63 \%$ dan $1.20 \%$ kepada $1.18 \%$ untuk $\mathrm{CH} 1450$ dan $\mathrm{CH}$ 2300. Oleh itu, FEM dilihat sebagai kaedah terbaik untuk menentukan lembangan pesongan FWD berbanding dengan program komputer MET yang lain.

Kata kunci: Unsur terhingga, KENLAYER, EVERSTRESS 5.0, penggantungan berat dadan, turapan boleh lentur

(C) 2020 Penerbit UTM Press. All rights reserved

\subsection{INTRODUCTION}

Flexible pavement is generally made up of asphalt material as the wearing course, with or without granular base or subbase layer. This type of pavement is called "flexible" pavement since, unlike "rigid" Portland cement concrete (PCC) roads, the total pavement structure will deflect or flex under traffic loading. Hence, pavement structures can be modelled in the effort to determine precisely what happen to the entire pavement. Pavement structures can be modelled and studied either analytically based on multilayered elastic theory (MET) or numerically based on finite element method (FEM), finite difference method (FDM), and discontinuous element method (DEM) [1-3]. The main purpose for modelling pavement structures is to determine the primary responses of the model, such as stress, strain, and displacement. However, this study focuses only on modelling pavement structures by using different methods in order to determine surface deflections at different sensors location in a Falling Weight Deflectometer (FWD) test.

FWD is the most widely accepted and used test for examining the structural integrity of pavement structures in a nondestructive manner, especially in pavement rehabilitation and management. In FWD test, an impulse load is applied to pavement surface by dropping a mass weight onto a circular plate with a rubber seal placed between the plate and pavement surface to prevent direct impact of the load. Surface deflections are measured directly below the plate by using several sensors or geophones at different radial offsets [2-5]. One major use of the FWD data is for performing back- calculation analysis $[6,7]$. The elastic moduli of each layer of pavement structure can be derived from the deflection basin of FWD test by using backcalculation and several other techniques $[2,3,5,8]$.

There are two directions in back-calculation analysis, forward and backward. In the forward process, deflections are calculated using structural analysis techniques based on information such as thickness of pavement layers, initial mechanical properties, loading, etc. Multilayered elastic theory, finite element method, and finite difference method are examples of structural analysis techniques employed to obtain calculated deflections. In the backward process, which is also known as inverse mapping, calculated deflections that were obtained from forward analysis are compared with measured deflections from the FWD test [2, 3, 9-11]. Therefore, in this study, the KENLAYER and EVERSTRESS 5.0 computer programs were used to model pavement structures which represent layered elastic theory, while ANSYS was used to model a pavement structure which represents FE method.

The KENLAYER computer program was originally developed at the University of Kentucky by Huang [12]. The basic component of KENLAYER is the multilayered elastic system under a circular loaded area. The KENLAYER can also analyze pavement structures with up to 19 layers with each layer being either linear elastic, nonlinear elastic, or linear viscoelastic [12, 15-16].

Since KENLAYER is an American computer program, both US customary units and metric units are available in this program [16]. KENLAYER also can be employed for layered system under single, dual, dual-tandem, or dual-tridem wheels by using the 
superposition principle to produce multiple wheels from a single wheel. The same superposition principle can also apply to a nonlinear elastic system by using successive approximations [12, 16-17]. For a viscoelastic system, the responses under a static load are expressed as a seven-term Dirichlet series while the responses under a moving load are obtained by assuming the loading to be a haversine function and applying Boltzmann's superposition principle to the Dirichlet series [12].

Mahasantipiya [15] used the OUPAVE and KENLAYER computer programs to determine pavement responses such as deflection, stress, and strain after obtaining the material properties for all layers through the MODCOMP3 back-calculation program. OUPAVE is based on finite element model which was developed at the Center for Geotechnical and Groundwater Research (CGGR) at Ohio University. A comparative study of OUPAVE and KENLAYER shows that the differences in the deflection and strain data produced by both programs are very small. Damage analysis was also conducted on two different models, namely the Asphalt Institute (Al) and Shell models, by using in KENLAYER. There is only a small difference in the data generated by the two models.

Chen et al. [17] reviewed five computer programs namely two 2D axisymmetric finite element programs (ILLI-PAVE and MICH-PAVE), one 3D finite element program (ABAQUS) and two multilayered elastic programs (DAMA and KENLAYER) to determine the most appropriate computer program for analyzing a structural pavement routinely. As DAMA gave the intermediate maximum surface deflection, compressive strain, and tensile strain in nonlinear analysis, satisfied the natural boundary condition required the least of input variables and also can considers dual-wheel loading, this study suggested that DAMA computer program is probably the best one to use routinely in designing of pavement structural. A comparison between three of computer programs: ABAQUS, DAMA and KENLAYER in studying the effect of dual wheels on the pavement structure shows the KENLAYER gave the maximum surface deflection for all three cases. However, the running time of KENLAYER is the least compared to others computer programs [17].

Gedafa [18] compared the outcome of using KENLAYER and Highway Development and Management (HDM-4) computer programs to analyze the performance of a flexible pavement in the Mumbai Metropolitan Region (MMR), India. KENLAYER was used to develop distress models in order to determine the damage ratio of the pavement structure. HDM-4 was also used to develop pavement deterioration models to predict the performance of the pavement structure. Results show that KENLAYER has a good ability to predict the performance of flexible pavements. The life span of pavement predicted by HDM-4 is less than that predicted by KENLAYER. This study also recommends the use of $\mathrm{Al}$ design method for determining the design life of pavement structure by using the spectrum of axle approach in the KENLAYER computer program.

The EVERSTRESS 5.0 computer program was developed at the Washington State Department of Transportation by Sivaneswarem, Pierce and Mahoney and is based on WESLEA layered elastic analysis computer program provided by the Waterways Experiment Station, U.S Army Corps of Engineer. EVERSTRESS 5.0 was also developed in a Microsoft Windows version and is capable of modelling pavement structure as a multilayered elastic system by using multiple wheels of up to 20 loads. EVERSTRESS 5.0 can handle up to five layers and can take into account the stress-sensitive characteristics of unbound pavement materials. The interface between two layers can be specified as either un-bonded or fully bonded. This computer program is capable of making calculation in both US customary units and in metric units [19-21].

Aderinola [19] developed pavement structure models by using the EVERSTRESS 5.0 to analyze the failure criterion for various material for base layer. Two materials for base layer namely soil cement (SC) and cement treated gravel base (CGTB) were used and compared with the conventional aggregate base. The Young Modulus and Poisson ratio values for these materials were determined through the backcalculation process as performed by Claros et al. in 1986 [19]. Pavement structure models developed for various modulus of asphalt concrete layer, $100 \mathrm{MPa}$ of subgrade and based on 0.5 and 2.5 million Equivalent Single Axle Load (ESAL) for SC and CTGB, respectively. A comparison between the $S C$ and aggregate base layers shows at a low ESAL 10.5 million repetitions), the aggregate base layer is better than the SC base layer. Whereas at high ESAL $(2.5$ million repetitions) or heavy traffic load, the CTGB layer shows better performance than the aggregate base layer.

Loulizi et al. [20] used several computer programs based on the layered elastic theory such as KENLAYER, BISAR 3.0, ELSYM5, and EVERSTRESS 5.0 and two finite element approaches, namely MICHPAVE and $A B A Q U S$ computer program, to compare the measured vertical compressive stress and measured transverse horizontal strain under the hot mix asphalt layer induced by a $25.8 \mathrm{kN}$ single tire and a $39.5 \mathrm{kN}$ set of dual tires to those calculated using layered linear elastic theory. Results show that all computer programs based on layered elastic theory produced the same responses to single and dual tire loading. This study recommended the use of more theoretical modelling, such as different material properties and different layer interface, and taking into consideration dynamic loading etc. to obtain a reasonable result for the comparison of measured and calculated responses. Ekwulo and Eme [21] designed a flexible pavement based on the three known CBR methods by using the layered elastic 
analysis computer program EVERSTRESS 5.0. Ekwulo and Agunwamba [22] also used EVERSTRESS 5.0 to analyze hypothetical asphalt pavement sections by using traffic load. A layered elastic analysis based on EVERSTRESS 5.0 computer program was employed to determine critical loading condition and minimum pavement thickness as well as to determine the fatigue and rutting strains for each subgrade moduli.

In recent years, the revolution in computer technology has led to the development of numerous computational techniques. The closed-form solutions or analytical methods are difficult to obtain or are not available for many engineering problems. Hence numerical methods are among of the best methods for solving many engineering problems. The Finite Difference Method (FDM), Finite Element Method (FEM), Boundary Element method (BEM), and MeshFree Method are some of the important numerical techniques which are available in the field of computational mechanics. Each of these methods has its own advantages and disadvantage [23]. FEM is tremendously popular for all engineering disciplines due to it is ability to model physical problems by means of mathematical algorithms. FEM can also model a wide range of problems from simpler linear problem to the most challenging problems.

Subsequent to the development of computer programs based on multilayered elastic theory, FE analysis was used for pavement research in the 1980s and this resulted in the two well-known FE computer programs, ILLIPAVE and MICHPAVE [24]. General purpose FE programs such as ABAQUS, ANSYS and ADINA can be used to develop pavement structure models with various pavement geometry, varying material properties and loading conditions, etc [25], [26]. Many research have been conducted by using FEM in pavement engineering of flexible and rigid pavement by virtue of the ability of FEM to handle structures with nonlinear materials, dynamic or moving loading, various boundary conditions, etc.

Tarefder and Ahmed [9] used FE method to perform dynamic and static analysis of FWD deflection basin which takes into account nonlinear materials. Both axisymmetric and quarter cube models were developed using the ABAQUS computer program to simulate the time-deflection histories of an FWD test. A comparison was made between dynamic, static, and field deflection basins and, the results of the analysis show that the deflection basins for both dynamic and static analysis are very similar to the field data. The result of static analysis, however, has more similarities with the field deflection basin in comparison to the dynamic deflection basin. The axisymmetric model also produced better results than the quarter cube model.

Cho et al. [27], for instance, compared three types of FE models, namely plane strain, axisymmetric, and 3D, using the ABAQUS computer program. They discussed the advantages and disadvantages of all models. One of the issues frequently raised by the researchers regarding the use of FEM for pavement structures is how to produce a simple model which can reduce computational time while improving the accuracy of pavement responses. Additionally, engineering decisions need to be made concerning element size, aspect ratio of elements, type of model used, etc. Results show that axisymmetric and 3D model are most appropriate model for analyzing pavement structure model under traffic loading condition.

Sukumaran et al. [28] used FE analysis to determine the failure mechanism of a pavement structure under moving aircraft loads. The 3D flexible pavement was modelled using ABAQUS. Since the study used a 3D model, the researchers also discussed using $\mathrm{FE}$ modelling strategies to reduce computation time while maintaining the accuracy. They discussed the factors affecting overall time efficiency, which are mesh construction, mesh refinement, element aspect ratio, and material nonlinearities. The size of the 3D model was reduced by using symmetry. The results of the study show that symmetry can be used to predict pavement responses in the same way as a full model.

The FE method used to model structure by using small interconnected elements is called finite elements. The process of subdividing a body into equivalent finite elements is referred to as discretization, and it is the first step in a finite element analysis process. Each interconnected element is linked directly or indirectly to another element, either through a shared interface, node, boundary line, or surface. Nodes or nodal points are points at which the primary unknowns must be evaluated. Nodal lines, nodal planes, or a nodal surface is an interface between elements. The number of unknowns at a particular node is called nodal degrees of freedom (DOF) [29]. The most appropriate type of element, loads, and boundary condition or support to be used in an FE analysis should be chosen based on engineering judgement and understanding of the physics of the problem.

In general, the displacement, stress, strain, and force in structures or components which are caused by imposed loads without taking into account significant inertia and damping effects can be determined by conducting a static structural analysis. Steady-state loading and response of conditions are assumed to vary slowly with respect to time. In the ANSYS program, thin models show better performance with a direct solver while bulky models show better performance with an iterative solver [30]. In the FE method, the overall equilibrium equation for linear structural static analysis can be written as:

$$
[\mathrm{K}]\{\mathrm{q}\}=\{\mathrm{f}\}
$$

where $[K]$ is total stiffness matrix, $\{q\}$ is total nodal displacement vector, and $\{f\}$ is total load vector. ANSYS will choose either a direct or iterative solver 
based on the type of analysis and model of geometry.

\subsection{METHODOLOGY}

The main objective of this study is to compare the deflection basin generated by three computer programs, KENLAYER, EVERSTRESS 5.0, and ANSYS, with the field measurements made in an FWD test. The pavement structure models developed for all computer programs based on the FWD analyzed data is provided by Edgenta Environmental \& Material Testing Sdn. Bhd. They conducted an FWD test on Jalan Negeri (P10) from Batu Maung to Jalan Sultan Azlan Shah, Pulau Pinang, Malaysia. Although the pavement evaluation report for this site shows that the FWD tests were conducted at 94 locations, this study chooses only three locations to develop a pavement structure model. The FWD test was performed by using the Dynatest device. Information on layer thickness was obtained from core logs while data on layer properties was obtained through backcalculation analysis using the ELMOD computer program.

In developing the pavement structure models for all computer programs, each model was assumed to be a multilayered elastic system which consists of four layers of pavement structure: asphalt concrete as the surface layer, followed by compacted granular material in the base and subbase layers. The bottom layer is the subgrade with natural soil. Each layer is modelled as linear elastic with the assumption that they are homogenous, isotropic material, and is characterized by Young modulus and Poisson ratio. The Young modulus value for each model is based on the results of the back-calculation of FWD test. The effect of Poisson ratio value on pavement structure behaviour is very minimal [12]. Thus, the value of Poisson ratio in this study is assumed to be 0.35 for the surface layer, 0.4 for the base and subbase layers, and 0.45 for the subgrade layer. Information about pavement thickness and material properties of the four locations of the FWD test are given in Table 1. In all computer programs, a static load with a pressure of $700 \mathrm{kPa}$ was applied on the $300 \mathrm{~mm}$ diameter loading plate.

Table 1 Layer thickness and properties of elastic material

\begin{tabular}{|l|l|c|c|c|}
\cline { 3 - 5 } \multicolumn{2}{c|}{} & \multicolumn{3}{c|}{ Point } \\
\cline { 3 - 5 } \multicolumn{2}{c|}{$\begin{array}{l}\text { Thickness } \\
(\mathbf{m m})\end{array}$} & $\mathrm{CH} 200$ & $\mathrm{CH} 1450$ & $\mathrm{CH} 2300$ \\
\cline { 2 - 5 } & Base & 240 & 220 & 170 \\
\cline { 2 - 5 } & Subbase & 10 & 363 & 182 \\
\hline $\begin{array}{l}\text { Modulus of } \\
\text { Elasticity } \\
(\mathbf{M P a})\end{array}$ & AC & 769 & 265 & 495 \\
\cline { 2 - 5 } & Base & 84 & 130 & 1016 \\
\cline { 2 - 5 } & Subbase & 103 & 231 & 201 \\
\cline { 2 - 5 } & Subgrade & 205 & 124 & 122 \\
\hline
\end{tabular}

${ }^{*} \mathrm{AC}=$ Asphalt Concrete
Figure 1 illustrates the layout of a multilayered elastic system in KENLAYER computer program for $\mathrm{CH} 200$. The semi-infinite pavement structure has four layers and, with the exception of the lower layer, each layer has a finite thickness; all layers are infinite in the lateral direction. The vertical deflection for all computer programs was measured for seven sensors located 0, 300, 600, 900, 1200, 1500 and $2100 \mathrm{~mm}$ from the $300 \mathrm{~mm}$ diameter load plate, as shown in Figure 1. No layout can be shown for EVERSTRESS 5.0 since it only requires input data. However, the layout of multilayered elastic system for both computer programs is similar.

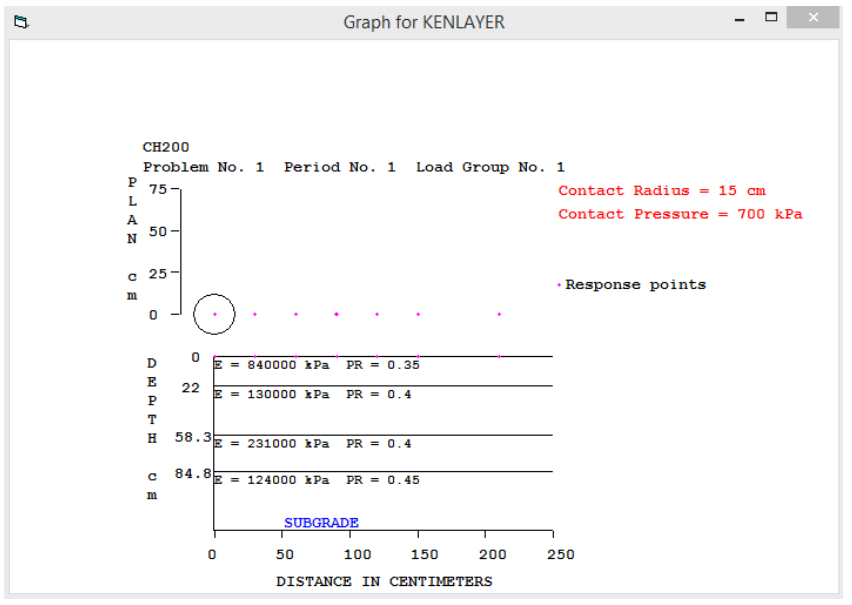

Figure 1 Layout of multilayered elastic system in KENLAYER

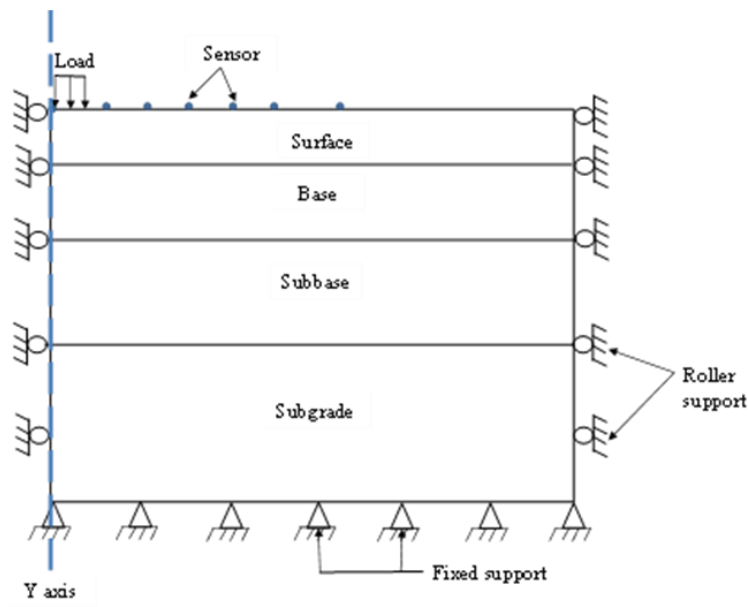

Figure 2 Axisymmetric model of flexible pavement

In FEM, an FE axisymmetric model of a multilayered flexible pavement structure $5000 \mathrm{~mm} x$ $5000 \mathrm{~mm}$ in the vertical and horizontal directions was developed to represent actual FWD test condition in the field. Each layer is assumed to be a linear elastic, isotropic homogenous material. A static load was applied to the FE model. Figure 2 shows the axisymmetric model of the pavement structure under FWD testing condition. It also shows the roller supports 
assigned to the vertical left and right of the model to restrain horizontal movement and only allow vertical movement. The bottom subgrade layer is assigned fixed support and no horizontal and vertical movements are allowed. The connection between two adjacent layers is assumed to be fully bonded with no gap. Slip is not allowed between two connected layers.

In order to perform an optimum analysis, the elements of the region closest to the loading area should have the finest mesh in comparison to the furthest region. Fine mesh increases the number of elements and requires much more computer memory and is more time consuming, but will produce more accurate results [31]. Figure 3 shows the mesh of an axisymmetric FE model. The surface, base, and subbase layers are meshed with $50 \mathrm{~mm}$ finer elements and the subgrade layer is meshed with $80 \mathrm{~mm}$ of coarse elements. The FE models were also meshed by using a four-node quadrilateral element (CAX4) with a quadratic interpolation function.

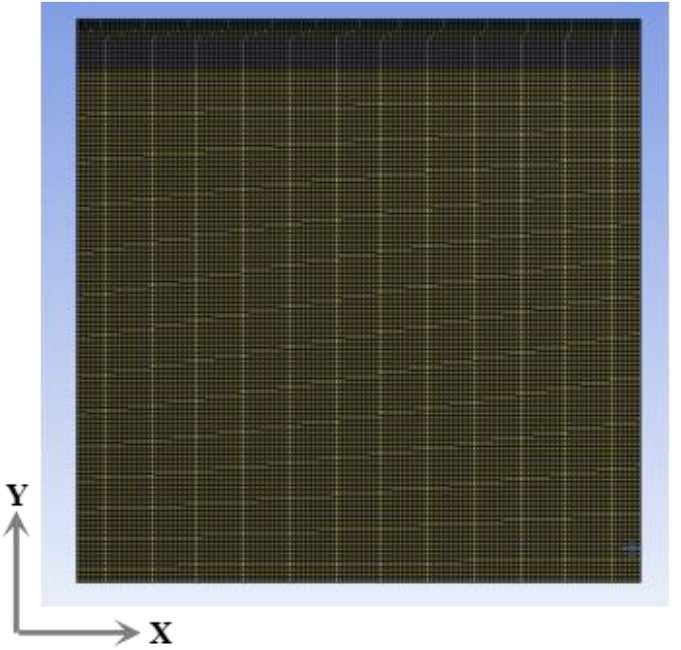

Figure 3 Mesh of FE Model

In this study the transient structural analysis used for FE analysis, which is also known as time-history analysis, is a technique used to determine the dynamic response of structures under any general time-dependent loads by taking into account inertia and damping effects. This type of analysis can also be used to determine time-varying displacement, strain, stress, and force under any combination of static, transient, and harmonic loads [30]. The basic equation solved by the transient structural analysis is:

$$
[\mathrm{M}]\{\ddot{\mathrm{u}}\}+[\mathrm{C}]\{\mathrm{u}\}+[\mathrm{K}]\{\mathrm{u}\}=\{\mathrm{P}\}
$$

where $[M]$ is mass matrix, $[C]$ is damping matrix, $[K]$ is stiffness matrix, $\{P\}$ is external force vector, $\{\ddot{U}\}$ is nodal acceleration vector, $\{u ́\}$ is nodal velocity vector, $\{U\}$ is nodal displacement vector.

\subsection{RESULTS AND DISCUSSION}

Figure 4 shows the comparison between the deflection basins from field measurement and the models developed using three computer programs for the three locations of the FWD test. The deflection is maximum at $0 \mathrm{~mm}$ and diminishes with increasing distance. It can be seen that all deflection basins closely approximate the field deflection basin. The figure also shows that all KENLAYER models produced the highest surface deflection values, especially for the second sensor when compared with the values produced by EVERSTRESS 5.0 and ANSYS. Studies conducted by Mahasantipiya [15], Chen et al. [17] and Ghadimi et al. [32] have also proven that KENLAYER overestimates surface deflection. However, in order to determine the approximation of deflection basins to field deflection basin, calculation using the percentage of RMSE was performed.

Figure 4(a) shows that the deflection basin determined by EVERSTRESS 5.0 for $\mathrm{CH} 200$ is a very close approximation of the field deflection basin with an RMSE of only $1.00 \%$. The deflection basins shown in Figure 4(a) depict a good correlation with the field deflection basin with the percentage of RMSE ranging between $2.41 \%$ and $2.94 \%$ for the ANSYS and the KENLAYER, respectively. For CH 1450, however, Figure $4(\mathrm{~b})$ shows that the deflection basin produced by KENLAYER gives the closest approximation to field deflection basin with an RMSE of $3.63 \%$. The deflection basins produced by ANSYS and EVERSTRESS 5.0 have RMSE of $4.21 \%$ and $4.31 \%$, respectively. It also can be observed that both computer programs underestimate the values for vertical deflections for each sensors and that these deflection basins also the closest each other. This is not unusual since FEM generally is slightly stiffer than the actual analytical solution [32].

Figure 4(c) shows that the deflection basins produced by EVERSTRESS 5.0 and ANSYS are very similar to the field deflection with RMSE of $1.19 \%$ and $1.20 \%$, respectively. The correlation for the deflection basin produced by KENLAYER and that from field measurement is satisfactory with an RMSE of $3.40 \%$. 


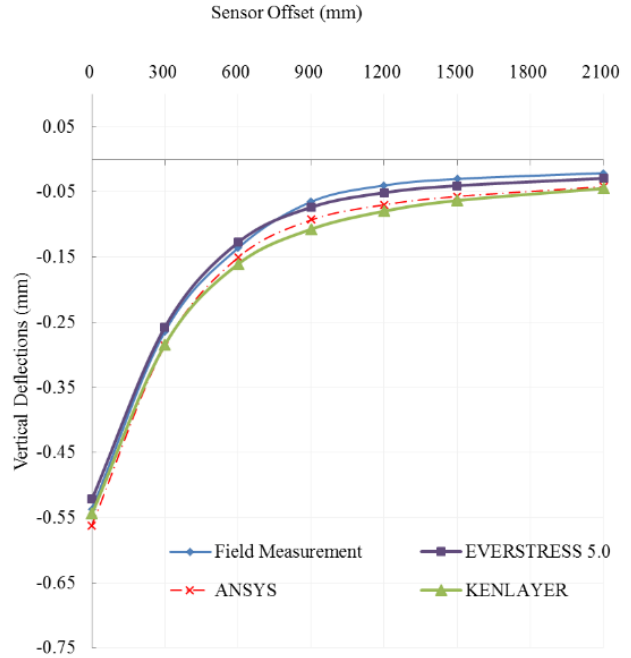

(a)

$\mathrm{CH} 200$

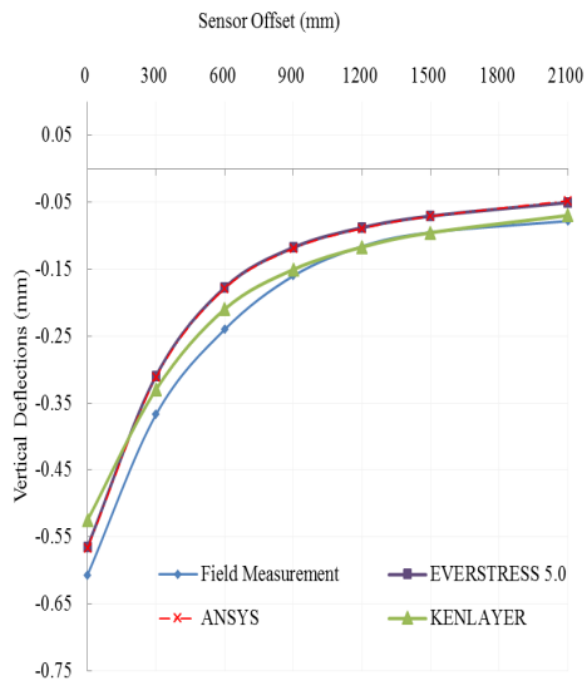

(b)

$\mathrm{CH} 1450$

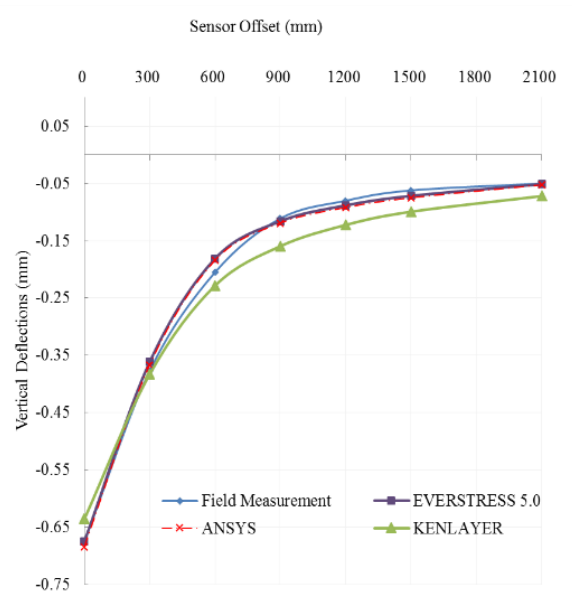

(c)

$\mathrm{CH} 2300$
Even though all values produced by the computer programs show a good correlation with field deflection basin with the percentage of RMSE less than 5.0\%, the FE method has the advantage of improving the accuracy of the developed model when compared to other computer programs. The FE method can take into consideration more controlling parameters, such as dynamic loading, viscoelastic and nonlinear elastic behaviour, size of model geometry, meshing, etc. Loulizi et al. [20] also recommended using more theoretical modelling in FE model in order to make a reasonable comparison between measured responses and predicted theoretical responses. Therefore, in order to increase the accuracy of deflection basin for FE method, the following sequence was performed in this study to converge the value of the deflection basin of $\mathrm{FE}$ model with that of the field measurement: first, change from static to dynamic load by using the available FE model. If there is no improvement in accuracy, then the size of model geometry is increased to $10000 \mathrm{~mm} \times 10000 \mathrm{~mm}$ and modelling is then done with static load, followed by dynamic load. The final alternative in the effort to increase accuracy is decreasing the size of elements.

Table 2 shows that the percentage of RMSE decreases from $2.41 \%$ to $0.94 \%$ when a dynamic load was applied to $\mathrm{CH} 200$ in the FE model. However, changing from static to dynamic load increases the percentage of RMSE slightly from $4.21 \%$ to $5.01 \%$ and $1.20 \%$ to $1.57 \%$ for $\mathrm{CH} 1450$ and $\mathrm{CH} 2300$, respectively. It can be concluded that FE model is more accurate when a static load is applied to both of locations, as have been proven in a study conducted by Tarefder and Ahmed [9]. Therefore, in order to obtain a higher accuracy for both $\mathrm{CH} 1450$ and $\mathrm{CH}$ 2300, the size of model geometry was increases from $5000 \mathrm{~mm} \times 5000$ $\mathrm{m}$ to $10000 \mathrm{~mm} \times 10000 \mathrm{~mm}$ by applying a static load in the FE model. Increasing the size of model geometry decreases the percentage of RMSE slightly from $4.21 \%$ to $4.10 \%$ for $\mathrm{CH}$ 1450. However the percentage of RMSE increased slightly from $1.20 \%$ to $1.24 \%$ for $\mathrm{CH} 2300$. Another alternative for obtaining a better of FE model is decreasing the size of elements, especially the elements that are closest to the loading region. For $\mathrm{CH}$ 1450, a $10000 \mathrm{~mm} \times 10000 \mathrm{~mm}$ geometry size for the FE model was developed and meshed with $30 \mathrm{~mm}$ of finer elements and $50 \mathrm{~mm}$ of coarser elements. For $\mathrm{CH} 2300$, a $5000 \mathrm{~mm} \times 5000 \mathrm{~mm}$ geometry size with $20 \mathrm{~mm}$ of finer elements and $50 \mathrm{~mm}$ of coarser elements for the bottom layer is used. Altering the size of elements reduces percentage of RMSE slightly from $4.21 \%$ to $3.63 \%$ and $1.20 \%$ to $1.18 \%$ for $\mathrm{CH} 1450$ and $\mathrm{CH} 2300$, respectively.

Figure 4 Deflection basin for all computer programs 
Table 2 Comparison of Percentage of RMSE for FE Method

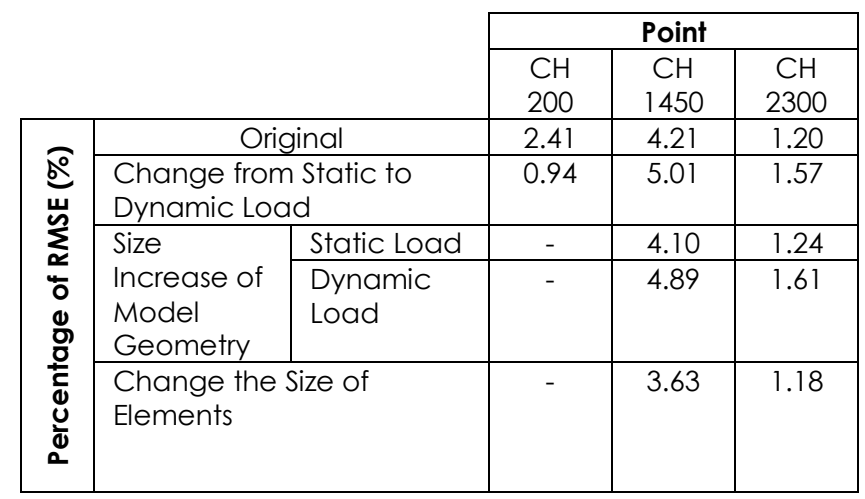

Table 3 shows the percentage of RMSE for ANSYS, EVERSTRESS 5.0, and KENLAYER computer programs for the determination of deflection basins when compared to vis-a-vis field deflection basin. After taking into account dynamic load, increasing the size of model geometry, and changing the size of the elements of the FE model, ANSYS produced the highest accuracy for all locations with the percentage of RMSE of $0.94 \%, 3.63 \%$ and $1.18 \%$ for $\mathrm{CH} 200, \mathrm{CH} 1450$ and $\mathrm{CH}$ 2300, respectively. As can be seen in Table 3, other computer programs could give a good determination of deflection basin with the percentages of RMSE ranging from $1.00 \%$ to $4.31 \%$ for EVERSTRESS 5.0 , and $2.94 \%$ to $3.63 \%$ for KENLAYER computer programs.

Table 3 Comparison of Percentage of RMSE of the Three Computer Programs

\begin{tabular}{|l|l|c|c|c|}
\cline { 3 - 5 } \multicolumn{2}{c|}{} & \multicolumn{3}{|c|}{ Point } \\
\cline { 3 - 5 } \multicolumn{2}{c|}{} & $\mathrm{CH}$ & $\mathrm{CH}$ & $\mathrm{CH}$ \\
\hline \multirow{2}{*}{$\begin{array}{l}\text { Percentage } \\
\text { of RMSE (\%) }\end{array}$} & ANSYS & 0.94 & 1450 & 2300 \\
\cline { 2 - 5 } & EVERSTRESS 5.0 & 1.00 & 4.63 & 1.18 \\
\cline { 2 - 5 } & KENLAYER & 2.94 & 3.63 & 1.19 \\
\hline
\end{tabular}

\subsection{CONCLUSION}

Based on the results of the comparison of the three computer programs, the KENLAYER and EVERSTRESS 5.0 computer programs that are based on multilayered elastic theory and the ANSYS that is based on the FE method produced good results for the vertical deflections of each sensor of the FWD test. These computer programs also have a good ability to simulate FWD test on pavement structures to determine the deflection basin of an FWD. The percentage of RMSE for all computer programs range from 1.00 to $4.31 \%$. Consideration was then made to increase the accuracy of the FE model either by changing from static to dynamic load, increasing the size of model geometry, or changing the size of elements. The percentages of RMSE for all locations decreased between $0.02 \%$ and $1.47 \%$ after implementing some of these alternatives. In conclusion ANSYS, which is based on FE method, is the most flexible and versatile computer program for modelling FWD test in order to determine deflection basin.

\section{Acknowledgement}

The authors would like to express their gratitude to Universiti Kebangsaan Malaysia for the financial support for this work (GUP-2018-094).

\section{References}

[1] E. Pan, E. Chen, W. Alkasawneh. 2008. Layered Flexible Pavement Studies: Challenges in Forward and Inverse Problems. Int. J. Pavement Res. Technol. 1: 12-16.

[2] A. B. Goktepe, E. Agar, a. Hilmi Lav. 2006. Advances in Backcalculating the Mechanical Properties of Flexible Pavements. Adv. Eng. Softw. 37: 421-431. Doi:10.1016/j.advengsoft.2005.10.001.

[3] A. H. Lav, A. B. Goktepe, M. A. Lav. 2009. Backcalculation of Flexible Pavements using Soft Computing. Intell. Soft Comput. Infrastruct. Syst. Eng. Springer. 67-106.

[4] K. Tawfiq, J. Armaghani, J. Sobanjo. 2000. Seismic Pavement Analyzer vs. Falling Weight Deflectometer for Pavement Evaluation: Comparative Study. Nondestruct. Test. Pavements Backcalc. Modul. Third Vol. ASTM International.

[5] R. Hadidi, N. Gucunski. 2010. Comparative Study of Static and Dynamic Falling Weight Deflectometer Backcalculations Using Probabilistic Approach. J. Transp. Eng. 136: 196-204.

[6] P. E. Sebaaly, S. Bemanian, S. Lani. 2000. Nevada's Approach to the Backcalculation Process. Nondestruct. Test. Pavements Backcalc. Modul. Third Vol. ASTM International,

[7] S. N. Shoukry, D. R. Martinelli, O. I. Selezneva. 1996. Dynamic Considerations in Pavement Layers Moduli Evaluation Using Falling Weight Deflectometer. Nondestruct. Eval. Bridg. Highw., International Society for Optics and Photonics. 109-121.

[8] I. N. Abdallah, S. Nazarian. 2009. Rapid Interpretation of Nondestructive Testing Results Using Neural Networks. Intell. Soft Comput. Infrastruct. Syst. Eng., Springer. 1-19.

[9] R. A. Tarefder, M. U. Ahmed. 2014. Modeling of the FWD Deflection Basin to Evaluate Airport Pavements. Int. J. Geomech. 14: 205-213.

Doi:10.1061/(ASCE)GM.1943-5622.0000305.

[10] L. H. Irwin. 2002. Backcalculation: An Overview and Perspective. Pavement Eval. Conf. 2002, Roanoke, Virginia, USA.

[11] K. Gopalakrishnan, M. R. Thompson, A. Manik. Rapid Finite-element Based Airport Pavement Moduli Solutions using Neural Networks. 3 (n.d.): 63-71.

[12] Y. H. Huang. 2004. Pavement Analysis and Design. Second ed. Prentice-Hall, Upper Saddle River, N. J.

[13] E. J. Yoder, M. W. Witczak. 1975. Principles of Pavement Design. John Wiley \& Sons.

[14] M. K. Charyulu, J. B. Sheeler. 1968. Theoretical Stress Distribution in an Elastic Multi-Layered System. Highw. Res. Rec. 11-17.

[15] S. Mahasantipiya. 2000. Performance Analysis of bases for Flexible Pavement. Ohio University. 
[16] H. Ziari, M. M. Khabiri. 2007. Interface Condition Influence on Prediction of Flexible Pavement Life. J. Civ. Eng. Manag. 13: 71-76.

[17] D.-H. Chen, M. Zaman, J. Laguros, A. Soltani. 1995. Assessment of Computer Programs For Analysis Of Flexible Pavement Structure. Transp. Res. Rec. 1482: 123133

[18] D. S. Gedafa. 2006. Comparison of Flexible Pavement Performance using KENLAYER and HDM-4. Midwest Transp. Consortium, Ames, lowa.

[19] O. S. Aderinola. (n.d.). Development of MechanisticEmpirical Pavement Design for Tropical Climate Using Cement-treated Base Layer.

[20] A. Loulizi, I. L. Al-Qadi, M. Elseifi. 2006. Difference between In Situ Flexible Pavement Measured and Calculated Stresses and Strains. J. Transp. Eng. 132: 574579.

[21] E. O. Ekwulo, D. B. Eme. 2009. Fatigue and Rutting Strain Analysis of Flexible Pavements Designed using CBR Methods. African J. Environ. Sci. Technol. 3.

[22] E. O. Ekwulo, J. C. Agunwamba. 2013. Layered Elastic Analysis and Design Tool for Predicting Fatigue and Rutting Strains in Low Volume Asphalt Pavement in Nigeria. Eur. J. Appl. Engrg Sc. Res. 22: 8-22.

[23] Y. M. Desai. 2011. Finite Element Method with Applications in Engineering. Pearson Education India,

[24] M. N. S. Hadi, B. C. Bodhinayake. 2003. Non-linear Finite Element Analysis of Flexible Pavements. Adv. Eng. Softw. 34: 657-662.
Doi:10.1016/S0965-9978(03)00109-1.

[25] M. Kim, E. Tutumluer, J. Kwon. 2009. Nonlinear Pavement Foundation Modeling for Three-dimensional FiniteElement Analysis of Flexible Pavements. 195-208.

[26] B. Saad, H. Mitri, H. Poorooshasb. 2005. Threedimensional Dynamic Analysis of Flexible Conventional Pavement Foundation. J. Transp. Eng. 131: 460-469.

[27] Y.-H. Cho, B. McCullough, J. Weissmann. 1996. Considerations on Finite-element Method Application in Pavement Structural Analysis. Transp. Res. Rec. J. Transp. Res. Board. 1539: 96-101. Doi:10.3141/1539-13.

[28] B. Sukumaran, M. Willis, N. Chamala. 2005. Three Dimensional Finite Element Modeling of Flexible Pavements. Adv. Pavement Eng. 1-12.

[29] D. L. Logan. 2011. A First Course in the Finite Element Method. Cengage Learning.

[30] ANSYS Workbench Help. 2017. ANSYS Release 18.0 ANSYS, Inc.

[31] C. Kuo, F. Chou. 2004. Development of 3-D Finite Element Model for Flexible Pavements. J. Chinese Inst. Eng. 27: 707-717. Doi:10.1080/02533839.2004.9670918.

[32] B. Ghadimi, H. Asadi, H. Nikraz, C. Leek. 2013. Effects of Geometrical Parameters on Numerical Modeling of Pavement Granular Material. Airf. Highw. Pavement 2013 Sustain. Effic. Pavements. 1291-1303. 